\title{
「“匠”の技の伝授」特集号によせで*
}

\section{原田朋 宏**}

入社して二十数年来, 机上のデスクマットの下に持 ち続け，折ある度に眺めている一枚の写真がある。ま だ新入社員当時の昭和 58 年, 職場配属前の現場実習 も終盤の頃, 進水を控えたある中東向忖新造タンカー の前で撮影したものである. 新品だった作業服も, 日々 の実習による污れと油に染まりながら，なんとか体に も馿染んでき, 学生気分から脱皮してそろそろ企業人 としての自覚が芽生え始めた頃である.

この頃までの僕等は昭和という時代の中にあって, 様々な変化にもまれながら, ある時はこれを乗り越え， またある時はこれをうまくがわしつつ何とか育ってき たように思う。教育の過程では先陣の団塊世代でピー クを迎えた受験戦争は偏差値教育という形で更に進化 し, 大学受験では国立大学共通一次試験（現在の大学 入試センター試験）の新制度適用元年を迎えた. ある 程度の “個” が尊重され, 比較的手厚く扱われながら も, 価值観の違いや世代間ギャップが取り沙汰され, 僕等を指して “新人類”といら総称が冠せられたのも ちょうどこの頃である.

企業人となった後も, 時代がもたらす変化と起伏は 留まることはなかった. 職場配属の時分はこの業界全 体が第二次オイルショックの余韻を引きずって疲弊状 態にあったし，昭和 60 年のプラザ合意による円高ド ル安政策は, 輸出が主体のこの業界の世界市場におけ る競争力を急速に䟣失させていった. 更には韓国や中 国などの新興勢力の台頭に追い討ちをかけられ，世の 中全体がバブル景気に沸き狂喜乱舞する時でさえ, こ の業界は満身創痍, 熾烈な国際競争を何とか切り抜け るべく, あらゆる手立てを尽くして穿地を淩いできた。 この間，今省みれば，手をあててはならない人材採用 抑制にまで手をあて, 写真に寄り添う同期の仲間も一 人また一人と去り, 未だこの事業に居残って, どっぷ りと首まで浸かって孤軍奮闘しているのは自らを含め 僅かに三名のみである. 今では, 団塊世代と団塊ジュ ニア世代の狭間にあって，指で弾けばポキリと折れそ うなワイングラスの最もか細い企業世代に身を置き， 背骨を軒ませながら会社を支えなければならない世代 となってしまった.

この写真は，そのような波乱に直面する前のそれぞ れが目指寸専門分野への正規配属を目前に控え，夢之 希望に胸膨らませながら, 背後のタンカー同様, 造船 マンとしての第一歩を正に踏み出そうとしていた，そ の時の一枚である.

*原稿受付 平成 18 年 8 月 21 日。

***正会員 (森) IHIMU 基本設計部 (港区海岸三丁目).
さて本題に入らねばならない，平成 17 年 11 月，東 京海洋大学に参集した学術講演会実行委員会では平成 18 年度春季学術講演会における各セッション,シンポ ジウムの講演テーマについての協議がなされた. 省工 ネ, 海洋環境, 代替然料, あるいは新材料やトライボ ロジ理論など, 当学会に馴染み深い学術分野での幾つ かのテーマ案が挙げられた。一つひとつ分類され整理 されていく中で，なかなか埋まらぬシンポジウムテー マの捻出に苦慮している時,「技術伝承を採り上げては どうだろう？」との意見が出された，そう言えば，時 代は正に熟練団塊世代の一斉少タイアという2007 年 問題に直面している. 自ら携わる造船業界も然り, こ れはひと頃の日本の高度経済成長支支えてきたあらゆ る“もの造り”現場が抱える喫緊の最重要課題である. 様々な思いが頭をよぎり，「やってみますか」というこ とになった.

本シンポジウムでは，まず金沢工業大学副学長の堀 幸夫先生に基調講演をお願いし，各業界の事業基盤を 技術面から支えていく工学系技術者の輩出機関である 大学の教育の現状についてご講演をいただいた。また この基調講演を踏まえ, シンポジウム講演会ではマリ ン業界の中心を担う 4 分野代表 6 社の方々加, 各社 で取り組まれている “技術・技能伝承, 後継者育成の 現場”についてご紹介いただき，マリン業界における 技術・技能の伝承とはどうあるべきか, 考察を試みた。

本特集号は，マリン業界の “技術伝承”を主題に， これらシンポジウム講演内容と一部追加寄稿分を織り 込み構成したもので，本稿を手に取られた皆さんがこ のテーマに思いを巡らす時, 少しでもお役に立てられ れば幸甚である. 最後に, シンポジウムでご講演いた だいた堀幸夫先生, 各社代表講演者の方々, また寄稿 いただいた執筆者の方々に厚くお礼申し上げます。

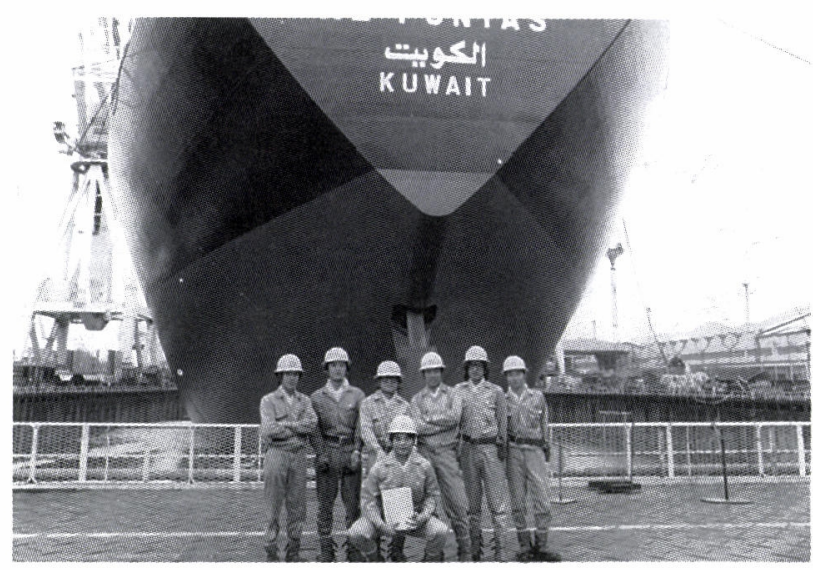

昭和 58 年当時の写真（後列右から 3 人目が著者） 


\section{「“匠”の技の伝授-マリン業界における技術伝承・ 後継者育成の現場」シンポジウム後記*}

原 田 朋 宏**

\section{1.はじめに}

平成 18 年 5 月 15 日（月）午後, 開催会場である東 京海洋大学越中島会館において,「“匠”の技の伝授 マリン業界に㧍ける技術伝承・後継者育成の現場」

( The Road to the "Meister" -Focusing the Succession and Training of Technical Skill in Marine Engineering Fields) のテーマを掲げ, 平成 18 年度春季学術講演会シンポジウムを開催した.

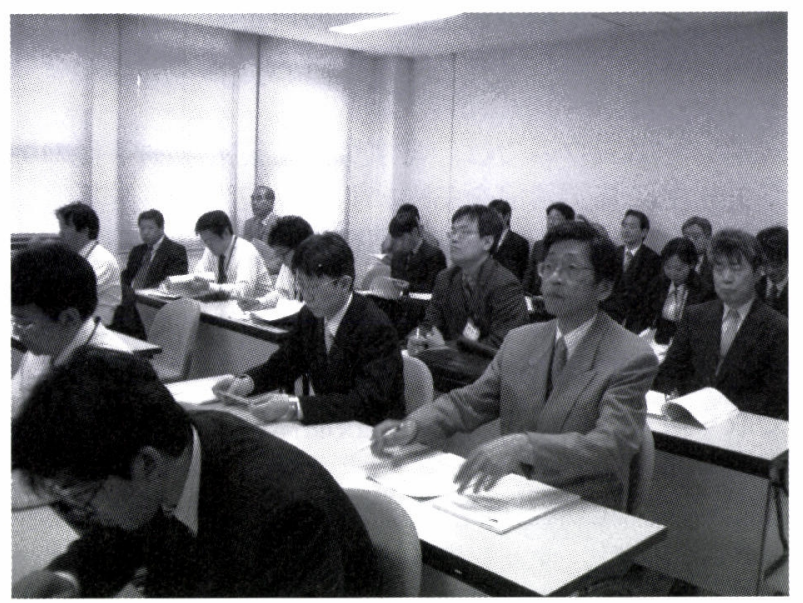

図 1 会場風景

ひと頃の我が国高度経済成長を支えてきた “もの造 り”現場では，熟練団塊世代の一斉リタイアという 2007 年問題に直面しており, 熟練技術者から若手後継 者への技術・技能の伝承, 後継者の育成・即戦力化が 喫緊の最重要課題となっている.ちょうど本年は当学 会創立 40 周年という節目の年を迎えるが，これ迄の 学会の長い歩みと共に, 様々な環境の変化と起伏に揉 まれながら浮沈の道程を辿ってきた “もの造り”現場 において，予見はされつつも招いてしまった人的資源 管理の問題，とりわけ我々が深く関わるところのマリ ン業界にお打る “技術・技能の伝承，後継者育成” いうテーマに焦点をあてて，今回のシンポジウムの開 催を試みた。

*原稿受付 平成 18 年 8 月 21 日

**正会員 (株 IHIMU 基本設計部（港区海岸三丁目）
本シンポジウムでは，まず金沢工業大学副学長・東 京大学名誉教授である堀幸夫先生より「大学の工学教 育の現状」というテーマで基調講演を行なっていただ いた．またこの基調講演を踏まえ，マリン業界の中心 を担う 4 分野代表 6 社の方々より, 各社で取り組まれ ている活動状況をご紹介いただき, マリン業界におけ る“技術・技能の伝承，後継者育成”とはどうある心゙ きか, 考察老試みた。

以下，シンポジウム後記として，その概要を報告寸 る.

\section{2. 基調講演「大学の工学教育の現状」}

堀先生の基調講演では，金沢工業大学において同大 学全体の共有理念として掲げ，これからの技術者にと って最も重要なテーマとなるであろう, “工学設計 ( Engineering Design) ”及び“技術者倫理 (Engineering Ethics)”の二つのテーマに焦点をあて たご講演老いただいた.

実社会で直面する問題・課題は，多くの場合におい てその解が多様であり，これからの実社会を担う工学 系技術者は, 大学教育の段階で, 解が多様な問題・課 題に触れさせ，自ら問題発見・問題解決に導くための プロセスを学ばせることが重要であるとされ，総合学 習的（問題指向型）指導法の下，同大学において実践 されている工学設計教育についてご紹介いただいた.

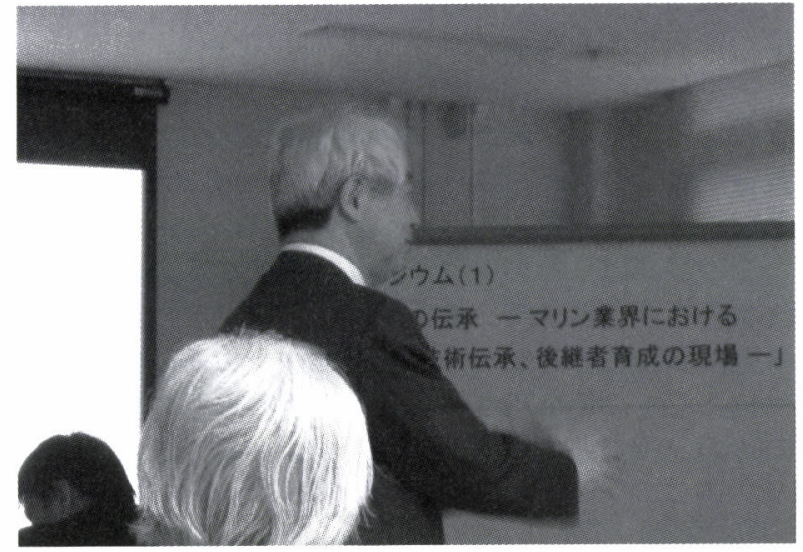

図 2 堀幸夫先生による基調講演 
また技術者倫理では，国内の各業界・企業において 発生している技術に関係する倫理上の問題事例を交え ながら，現代社会への技術の影響は大きく，これは即 ち社会に対する技術者の責任が極めて大きいことを意 味する，技術者は基本的素養として常に高い倫理観を 備え，技術者倫理教育は全ての技術教育のバックボー ンでなければならないと説かれ，同大学で取り組まれ ている技術者倫理教育についてご紹介いただいた.

最後に，伊勢神宮の遷宮のお話しをもとに，今回の シンポジウムテーマである技術伝承・後継者育成につ いても触れられ，“匠”の技を次の世代に継承するため に 20 年もの歳月をかけて殿舎の造営を繰り返す神宮 の遷宮のように，本来技術伝承とは長期にわたる育成 計画に従って対処す心゙き問題であり，猶予なき喫緊の 対応を迫られた今日では，あらゆる機会を捉えて，あ らゆる工夫を試みながら対処していくしかないのでは ないかとの所感が述べられた。

\section{3．マリン業界における技術伝承の現場}

\section{1 シンポジウム講演会}

シンポジウム講演会では, 造船, 舶用機器メーカー, 海運ならびに総合エンジニアリングの 4 部門代表 6 社 の方々より，各社において取り組まれている“技術・ 技能の伝承，後継者育成” の活動状況についてご紹介 いただいた。
各社講演テーマならびに代表講演者の方々は次のと おりである。

-「当社での機関艤装の技術伝承について」 (株)川崎造船 水口朋和氏

-「機関部艤装設計の技術伝承 一展望と課題一」 (株)IHI マリンユナイテッド 伊藤正樹氏

-「ナカシマプロペラにおける技術者の育成」 ナカシマプロペラ(株) 山崎正三郎氏

-「当社の技能伝承の取り組みについて」

(株)三造機械部品加工センター 多賀谷泰三氏

-「グローバル化社会での海技者の育成」

日本郵船(株) 岡崎一正氏

一「エンジニアリング業における技術伝承」

JFEエンジニアリング株 戸田伸一氏

表 1 に，各社講演内容から，技術・技能の伝承活動 が行われているフィールド（業種，業容，技術領域な ど)，その活動制度（スローガン），伝承体系と伝承期 間 (サイクル)，伝承方法（運用ツール），育成評価方 法（PDCA 体系の有無）とその達成レベルの測定方法 (評価ツール), ならびに経営サイドの関与状況につい てマトリクス様式に縓めたものを示す.

\begin{tabular}{|c|c|c|c|c|c|c|}
\hline & 川崎造船 & $\begin{array}{c}\text { IHII } \\
\text { マリンユナイテッド }\end{array}$ & ナかシマプロペラ & 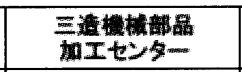 & 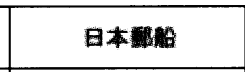 & $\begin{array}{c}\text { JFE } \\
\text { エンシニテリング }\end{array}$ \\
\hline Fields & 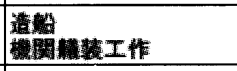 & 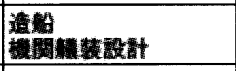 & 舶用プロベラ & 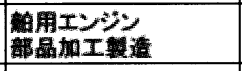 & 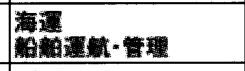 & 粠合エンジニフリング \\
\hline 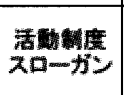 & 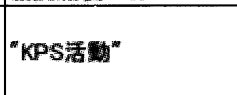 & 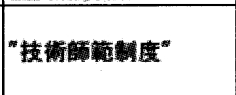 & & "找能研婥センター" & $\begin{array}{l}\text { "NYK Maririne } \\
\text { College" } \\
: \text { "エキスイーート21" }\end{array}$ & 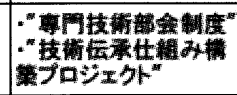 \\
\hline 坛承体系 & 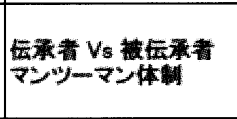 & 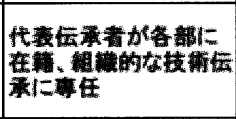 & 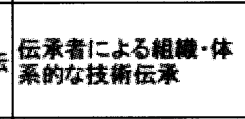 & 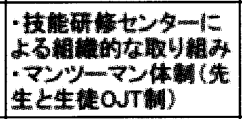 & 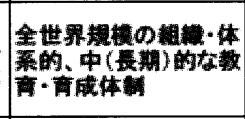 & 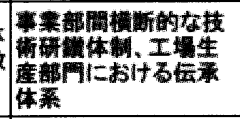 \\
\hline $\begin{array}{l}\text { 至承期閶 } \\
\text { オイル }\end{array}$ & 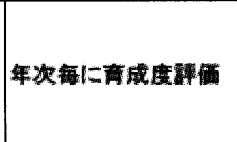 & 3年でー人剖を目指す & 中畏期的言成 & 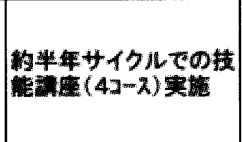 & 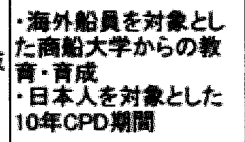 & 年次敏に育成·敉值 \\
\hline 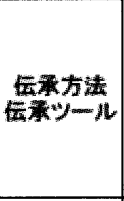 & 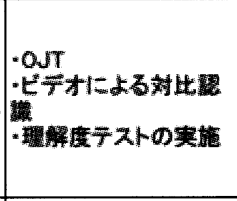 & 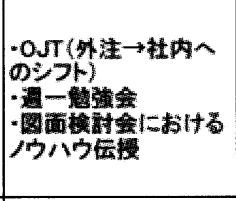 & 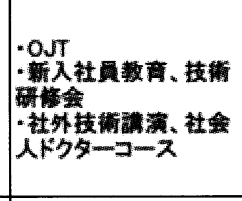 & 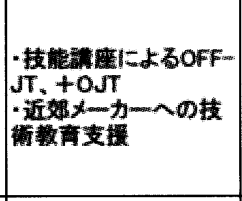 & 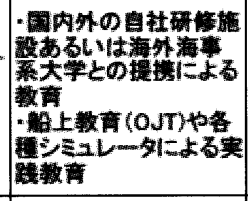 & 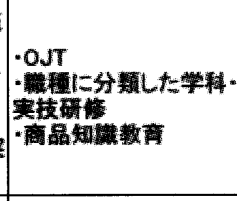 \\
\hline $\begin{array}{l}\text { 育成群留洼 } \\
\text { PDCA体系 }\end{array}$ & 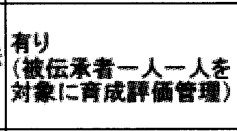 & & 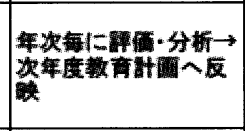 & 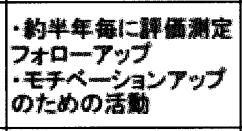 & 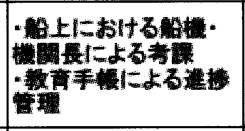 & 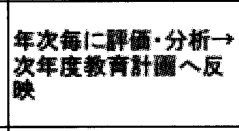 \\
\hline 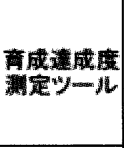 & 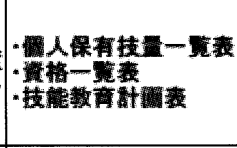 & & 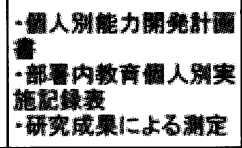 & -技转マックフ & 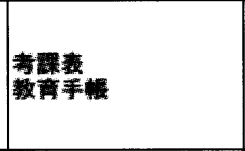 & 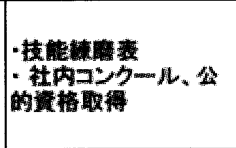 \\
\hline 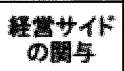 & 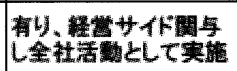 & 舴り (閣孝) & 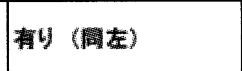 & 育り（周を） & 骨以 (調左) & 专以（成在） \\
\hline
\end{tabular}

表 1 各社における “技術・技能伝承，後継者育成” 活動の状況 
これを基に，改めて各社において取り組まれている 技術・技能伝承，後継者育成活動における特徴あるい はキーワードとなるポイントをレビューしてみると, 各社いずれも，その伝承体系，伝承方法あるいは目標 とする到達点などを包括した簡潔なキーワードで表現 されたスローガンを掲げて活動を展開されているよう である。これは実質的な活動主体となる熟練伝承者と 被伝承者のみならず, その活動の場における彼等を取 り巻く第三者にも効果的に浸透し, 目標到達点に向け ての組織的な推進力として寄与しているようである.

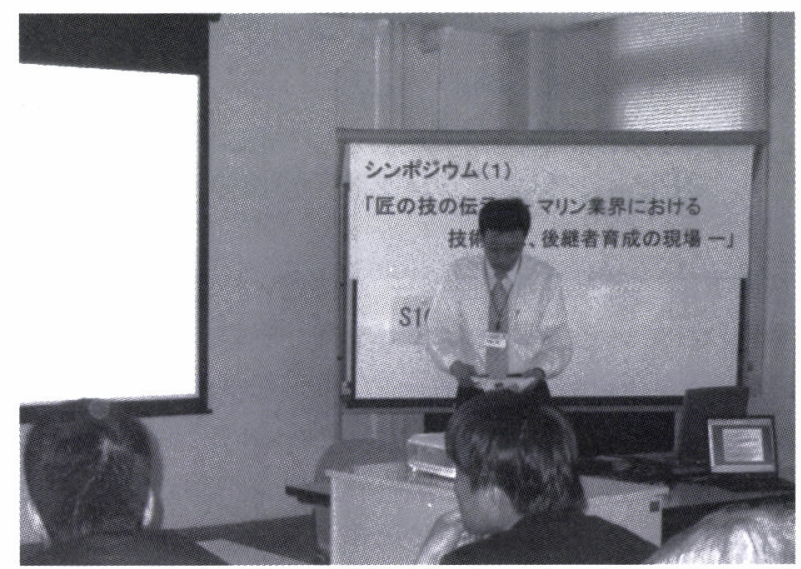

図 3 株)三造機械部品加工センター 多賀谷氏 講演

伝承体系及びその伝承方法の点では，各部署におい て任命された熟練技術者を中心に，日及の業務におけ る OJT 体制の下, 被伝承後継者に対しマンツーマン 体制で技術伝承・育成活動が行われている。

舶用ディーゼルエンジン製造の機械加工分野を一手 に担い，これをコア技術に据えて事業展開されている (株三造機械部品加工センタ一殿では, 機械加工技術の 専門研修機関としての“技能研修センター”を開設し, 同研修センターにおいて組織的かつ機能的な取り組み が行なわれているようである。

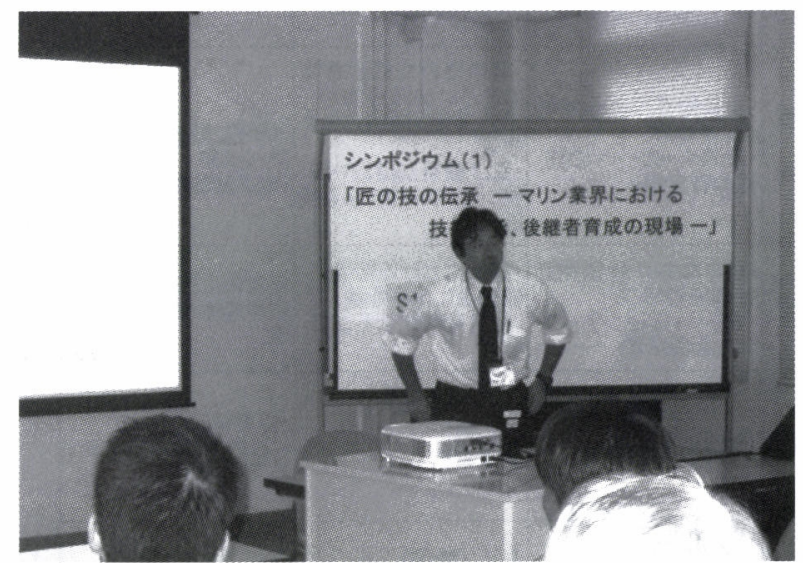

図 4 日本郵船(株) 岡崎氏 講演
また伝承期間では，PDCA サイクルにおける被伝承 者へのフィードバックタイミングあるいは中長的な人 事計画にも関係するものと考えられるが，年次毎から 約 3 力年毎をひとつの伝承サイクルとして期間計画が 計られている場合が多い。

但し一方で，国内船舶職員の不足が深刻化している 海運業界代表の日本郵船株殿の場合のように，その後 継者を海外に求め, 自社が運営する研修機関において, あるいはその育成の起点を大学教育にまで遡り，十年 レベルの教育期間をかけて育成教育が行われていると ころもある。

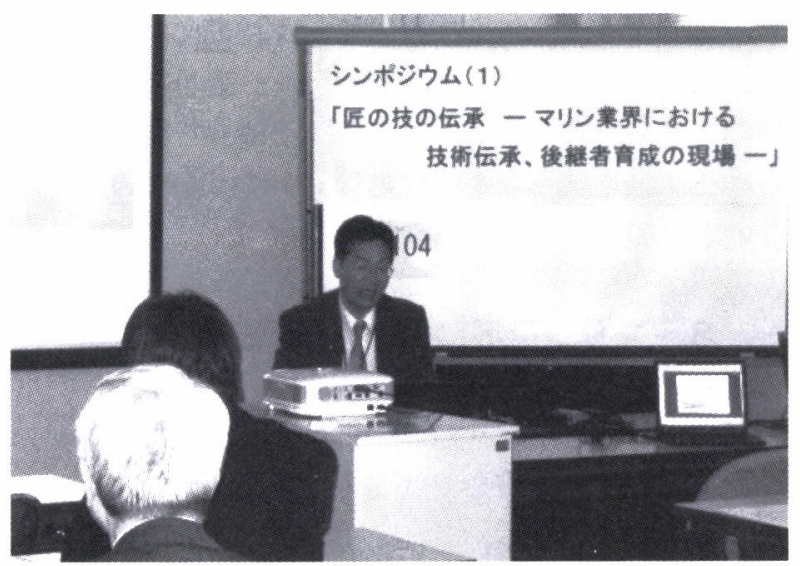

図 5 ナカシマプロペラ(株)山崎氏 講演

舶用プロペラ製造の分野で, プロペラの設計, 性能 解析及び研究開発が主体となるナカシマプロペラ(株殿 では，新人ステージにおける要素技術修得のための OJT, 中堅クラスでの専門研究テーマの付与とその成 果発表, あるいは大学とタイアップしての社会人ドク ターコースの導入など, 研究開発職としての能力開発 と深度ある技術力研鑚のため，段階的かつ体系的に期 間をかけた育成制度が採られているようである。

育成評価方法とその達成レベルの測定では, 各社共 伝承期間毎にPDCA サイクルをまわして,それぞれの フィールドに則した評価ツールを運用しながら, 被伝 承者への適切なフィードバックとこれ以降の教育計画 への確実な反映がなされていることがわかる.

職域的な領域が広く, 習得すべき技能が多岐にわた っている造船機関艤装工作分野の川崎造船株殿では, 個人保有技量一覧表，資格一覧表及び技能教育計画表 から成る “技量管理表”をもって, 被伝承者各人が到 達している技能レベルを定量的に数值化して評価し， これを育成過程の評価ツールとして運用され，あわせ て組織的な技術・技能マップとしても活用されている. 


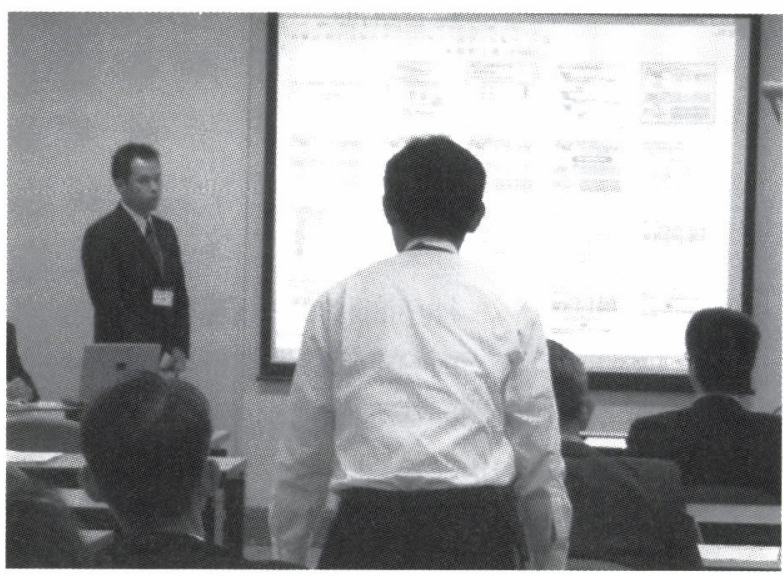

困 6 (株川崎造船 水口氏 講演

若干フィールドは異なるが，対象とする事業領域が 広範囲で，多様な技術力と技能を駆使することが要求 される総合エンジニアリング部門の JFE エンジニア リング(株殿においても，“技能練磨表”による被伝承者 各人の定量的な育成評価と，組織としての総合技術力 のポテンシャルアップに向けての技術伝承・育成活動 が行なわれている.

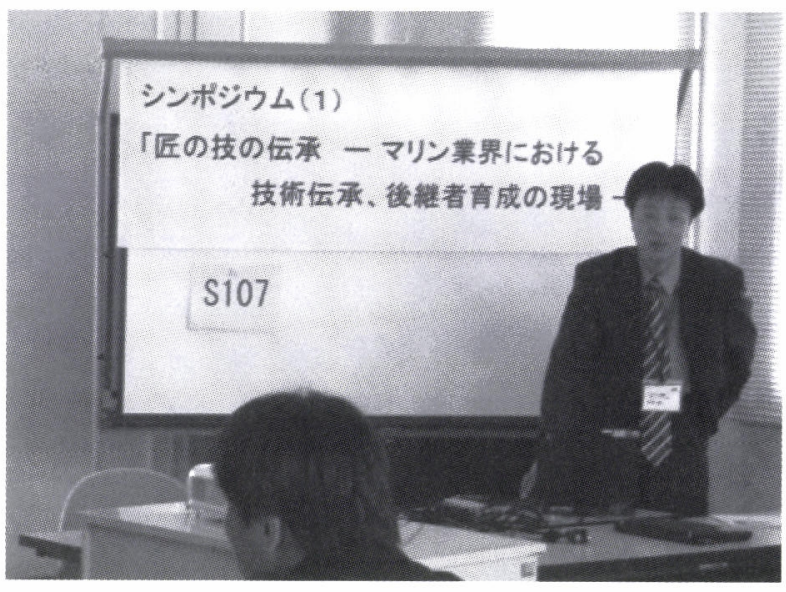

図 7 JFE エンジニアリング株) 戸田氏 講演

技術伝承というテーマにおいて, “暗黙知”と“形式 知”の習得・継承の問題はよく言われているところで あるが，形式的なマニュアルのみによる技術の継承が 困難で，経験の積み重水からもたらされるノウハウ・ センスによるところが大きい造船機関艤装設計分野の (株IHI マリンユナイテッド殿では，この業界では必然 的な業態として定着しつつあるアウトソーシングの一 部を取り崩し，ベテラン設計者を中心とした OJT 体 制の下，主要な設計業務を自社内に取り込み，これを 若手設計者に担当させ，設計ノウハウとセンスの蓄積 を自ら経験させる試みがなされている。これも若手後
継者の効果的な育成，即戦力化を図る上での，ひとつ の戦略的対処方法といえるのではないだろうか.

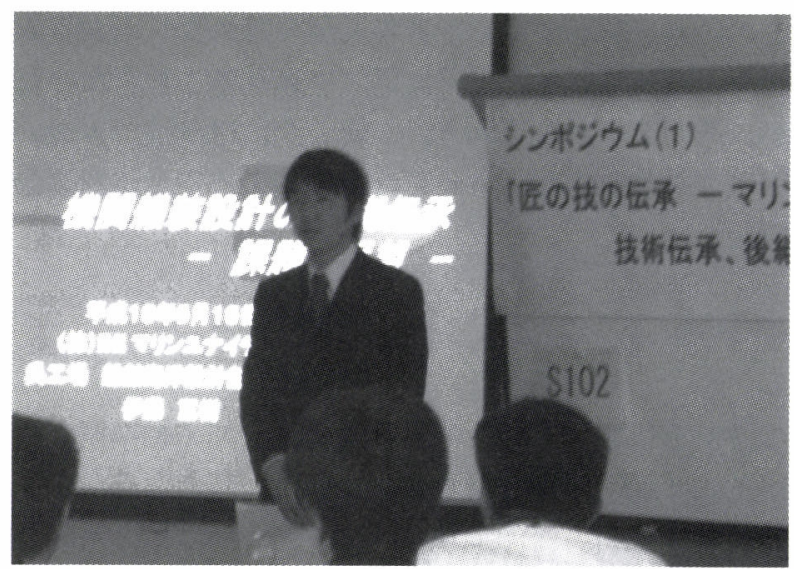

図 8 (株IHI マリンユナイテッド 伊藤氏 講演

“技術・技能の伝承，後継者育成”における経営サ イドの関与状況については，各社いずれもとりたてて 言うまでもなく，この喫緊の課題を事業存続に関わる 経営上の重要な問題として捉えられており，経営サイ ド自らが積極的にこの問題に関与し，このリーダシッ プの下，全社を挙げて組織的な活動として展開されて いる状況がよくわかった。

\section{2 全体討論会}

以上 6 テーマの講演の後, 聴講者の皆さんにもご参 加いただいての全体討論会を実施した。活発な質疑応 答と議論が交わされたが，その中で，船舶の軸系据え 付け工法に関わる大変興味深い議論が挙がったのでこ こにご紹介しておく

船舶の推進軸を支持する船尾管軸受けの船体（船尾 ボス）への据え付けには，専らボーリング押し込み工 法が採られてきたが，軸受けブッシュをある範囲内で の精緻な締め代をもつて摩擦力により船尾ボスに押し 込み，挿着するこの工法では，日照他の影響による船 尾部分の船体撓み量やツールとして用いるボーリング バーの撓みなど，この工法における様々な制約条件を 精密に測りつつ, 必要な加工修正を加えながら工程を 進めていく必要があり，長年の経験とノウハウに培わ れた熟練技能が要求される. 昨今，殆どの国内造船所 において，この工法を継承する技能職が減少の一途を 辿っており，その技術の継承が大きな問題として取り 沙汰されている。一方，最近の新たな工法として，硬 化樹脂剂を用いて軸受けブッシュを据え付けるレジン 工法があり, 国内造船所の各所において，この新工法 への移行・普及が進展しつつある. 旧来のボーリング 押し込み工法技術の途絶問題とこれに相対しての新工 法への移行についての是非論である。 
会場では，賛否両論，様々な意見が取り交わされた が，限られた時間内での討論であったこともあり議論 の結末を迎えるまでには至らなかった。

この話題を発端に，参加者各人が今回のシンポジウム テーマを持ち帰り，夫々に思いを馳せることとなった が，そのテーマの重みと，一朝一夕には到達できない 困難さを改めて認識させられた意義のある全体討論会 であった。

\section{4.おわりに}

本稿を執筆している今，全体討論会での軸系据え付 け工法の話題を著者なりに顧みれば，新たなレジン据 え付け工法は, 船舶の船尾管軸受けとしての完成品 質・機能・性能・信頼性がいずれも欠けることなく達 成できるとの前提の下, 従来工法の継承途絶問題を解 決できるひとつの工夫的手段として，この工法一の移 行，普及は “是”であると考える.

が，これはあくまで，定形的な，あるいは形式知的 な “技術” の範疇で対処できる領域の議論ではないだ ろうか．今回のシンポジウムにおいて，我々が目の当 りにし, 今後このテーマにおいて追究すべきところは, もっと無定形で暗黙知的な部分, 長年の経験の中で培 われ，本質的なものとして内在している/ウハウ，感 性の領域であり，この継承にはそのような内なる本質 的能力を備えた“人”の介在なしには到達でき得ない ものであると感じている.

一朝一夕には成ら㚥常に困難なテーマではあるが, 今回のシンポジウムをとおして得られた知見を顧みな がら，今後もこのテーマを正面から捉え対処していき たいと考えている.

当日は学術講演会開催初日であるにも関わらず, 会 場には約 70 名ほどの多数の聴講者の皆さんにご参集 いただき, 活発な議論も交わされ, 所期の企画に沿つ た盛況なシンポジウムを開催することができた．

最後に，今回のシンポジウム開催にあたり，快く基 調講演を引き受けて下さった堀幸夫先生，また今回の シンポジウム開催主旨にご賛同いただき, 講演のご協 力をいただいた代表各社の皆様に改めて厚くお礼申し 上げます。

\section{著者紹介}

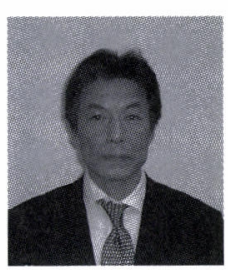

原田 朋宏

- 1960 年生

・株IHI マリンユナイテッド

基本設計部

- 神戸商船大学（現神戸大学）

商船学部機関学科卒

(E28)

·専門分野 : 商船機関部基本計画

・当学会活動では $\mathrm{H} 5$ 年から昨年まで企画委員を, また昨年より機関第 1 研究委員会副委員長を担当. 